\title{
Dampak Konflik Peran Terhadap Stres dan Kepuasan Kerja Karyawan PT. Jombang Intermedia Pers (Jawa Pos Radar Jombang)
}

\author{
Kristin Juwita ${ }^{1}$, Devy Arintika ${ }^{2}$ \\ 1,2 STIE PGRI Dewantara, Jombang, Indonesia
}

\begin{abstract}
The purpose of this research is to study the impact of role conflict on employee job satisfaction with job stress as mediation variable at PT. Jombang Intermedia Press (Jawa Pos Radar Jombang). This research used explanatory research with a quantitative approach to explain relationship of variables through hypothesis test. This study uses questionnaires distributed to 30 respondents of PT. Jombang Intermedia Pers (Radar Jombang) with saturated sampling method. The data analysis used Structural Equation Model using PLS (Partial Least Square) 5 version. This research find that role conflict has significant and positive influence to work stress. But, role conflict has a positive effect on job satisfaction, job stress positively influence to job satisfaction, while work stress is not able to mediate between role conflict to job satisfaction.
\end{abstract}

Keywords—Job Satisfaction; Job Stress; Role Conflict

\begin{abstract}
Abstrak
Tujuan penelitian ini meneliti dampak konflik peran pada kepuasan kerja yang dimediasi stres pada karyawan PT. Jombang Intermedia Pers (Jawa Pos Radar Jombang). Penelitian ini merupakan penelitian eksplanasi atau penjelasan melalui pendekatan kuantitatif. Data dikumpulkan melalui penyebaran angket pada 30 karyawan PT. Jombang Intermedia Pers (Radar Jombang) dengan metode sampling jenuh. Metode analisis dibantu oleh SEM (Structural Equation Model) dengan alat analisis PLS versi 5. Hasil penelitian menunjukkan adanya kontribusi signifikan dan positif antara konflik peran pada stres kerja. Namun, justru konflik peran berdampak positif terhadap kepuasan kerja, dan stres kerja berdampak positif terhadap kepuasan kerja. Adapun stres kerja tidak mampu memediasi dampak konflik peran terhadap kepuasan kerja.
\end{abstract}

Kata kunci- Konflik Peran; Kepuasan Kerja; Stres Kerja

\section{PENDAhUluAN}

Selama beberapa dekade terakhir, kepuasan kerja telah menjadi topik penelitian yang hangat karena topik tersebut berhubungan positif dengan kualitas layanan, komitmen organisasi, niat bertahan dalam perusahan, dan hal positif lainnya yang berkenaan dengan organizational citizenship behaviors (Gu \& Chi Sen Siu, 2009; Jung \& Yoon, 2015). Kepuasan kerja mengacu pada kesukaan atau tingkat emosional yang positif dari seorang individu yang terjadi karena hasil atau pengalaman dari suatu pekerjaan. Dengan kata lain, kepuasan kerja menunjukan sikap positif yang ditunjukan kepada karyawan mengenai pekerjaannya (Kong, Jiang, Chan, \& Zhou, 2018). Dalam sebuah industri, salah satunya adalah industri media cetak, seorang karyawan dituntut untuk selalu memberikan yang terbaik bagi perusahaan, yaitu kinerja yang baik serta sikap profesional dalam melakukan semua pekerjaannya. Karyawan dikatakan memiliki sikap profesional jika memiliki sikap patuh terhadap peraturan, budaya, norma, dan Standard Operation Procedure (SOP) yang ditetapkan perusahaan (Akwan, Suprapti, \& Sintaasih, 2016). Namun, apabila peraturan dirasa kurang baik karena tidak sesuai dengan tata nilai, kebiasaan dan proses bekerja yang dilakukan sebelumnya akan menimbulkan konflik peran dan tentu saja akan berdampak pada kepuasan kerja karyawan (Alfian, Adam, \& Ibrahim, 2018).

\section{Article info}

Received (9 ${ }^{\text {th }}$ April, 2018)

Revised (2 ${ }^{\text {nd }}$ May, 2018)

Accepted (26 ${ }^{\text {th }}$ July, 2018)

Corresponding_author: kristinjuwita66@gmail.com 
Konflik peran muncul akibat ketidakonsistenan antara mekanisme kontrol birokrasi dengan prinsip, etika, kemandirian profesional dan norma (Hanif, 2013). Hal tersebut muncul dikarenakan banyaknya pekerjaan yang harus dikerjakan oleh karyawan dalam satu waktu (Nur, Hidayati, \& Maria, 2017) pengharapan yang sulit untuk dipenuhi atau dipuaskan. Stres kerja dan menurunnya kepuasan kerja merupakan beberapa dampak yang disebabkan oleh konflik peran (Robbins \& Judge, 2015). Selain konflik peran, pihak perusahaan juga harus waspada dengan stres kerja yang mungkin dialami oleh karyawan. Kondisi stres kerja merupakan suatu kondisi tegang yang dialami oleh karyawan atau seseorang disebabkan oleh keadaan yang mempengaruhi hal tersebut, dikenal sebagai stres (Handoko, 2008).

Radar Jombang yang sebelumnya merupakan kantor biro Jombang untuk Radar Mojokerto telah berkembang menjadi PT. Jombang Intermedia Pers. Radar Jombang baru berpisah dari Radar Mojokerto termasuk karyawannya sebagian pindah ke Radar Mojokerto. Kondisi tersebut ternyata tidak diimbangi dengan penambahan karyawan di kantor Radar Jombang dengan alasan efisiensi. Staf karyawan yang ada dimaksimalkan fungsinya yang berakibat kepuasan kerja karyawan yang menurun. Indikasi penurunan kepuasan kerja terbukti dari sulitnya karyawan menyelesaikan berbagai pekerjaan sesuai target yang telah ditetapkan perusahaan. Hal ini terjadi karena karyawan mengalami konflik peran. Konflik peran yaitu keadaan tegang saat individu sulit menyelesaikan berbagai pekerjaan dengan peran yang berbeda dalam satu waktu (Naibaho \& Sawitri, 2018).

Karyawan Radar Jombang yang awalnya hanya memegang satu tugas dalam pekerjaan, saat ini dituntut untuk bisa menyelesaikan dua hingga tiga bidang pekerjaan sekaligus dalam waktu yang sama. Selain itu, banyak pekerjaan yang sebenarnya tidak sesuai dengan deskripsi pekerjaan awal karyawan dan belum tentu karyawan mempunyai kemampuan di bidang tersebut. Beban kerja dan tanggung jawab yang bertambah menyebabkan karyawan Radar Jombang stres. Stres atau perasaan tertekan terlihat dari karyawan yang merasa kesulitan memenuhi standar kerja sesuai ketetapan organisasi karena bingung pekerjaan mana yang harus diselesaikan dahulu (Prajuna, Febriani, \& Hasan, 2018). Hal ini memicu kecemasan, tersinggung, mudah marah, jenuh, menangis hingga mengalami gangguan kesehatan. Stres yang meningkat dapat berdampak pada penurunan kepuasan karyawan Radar Jombang terhadap pekerjaan, rekan kerja, atasan, bahkan imbalan yang diterima.

Adapun tujuan penelitin ini adalah untuk menjelaskan dan menganalisis pengaruh konflik peran terhadap stres kerja karyawan, pengaruh kepuasan kerja terhadap stres kerja karyawan, pengaruh konflik peran terhadap kepuasan karyawan, dan pengaruh konflik peran terhadap kepuasaan kerja karyawan yang dimediasi oleh stres kerja. Perumusan pertanyaan yang diajukan dalam penelitian ini yaitu: (1) apakah konflik peran berdampak pada stres seorang individu? (2) apakah stres kerja berpengaruh pada kepuasan kerja individu? (3) apakah konflik peran berpengaruh terhadap kepuasan kerja individu? dan (4) apakah stres kerja memediasi konflik peran terhadap kepuasan kerja?

Hasil penelitian diharapkan dapat memberikan manfaat bagi manajemen PT. Jombang Intermedia Pers (Jawa Pos Radar Jombang) dalam menentukan kebijakan yang tepat dalam mengoptimalkan potensi karyawan dan mampu mengendalikan konflik peran dan stres kerja karyawannya karena dapat berdampak pada kepuasan kerja. Selain itu, hasil penelitian ini akan memberikan tambahan informasi implementasi keilmuan manajemen sumber daya manusia terkait pengaruh konflik peran terhadap kepuasan kerja melalui stres kerja dalam suatu organisasi.

\section{KAJIAN LiterATUR DAN PENGEMBANGAN HiPOTESIS}

\section{A. Kepuasan Kerja}

Kepuasan kerja merupakan penilaian seseorang individu atas perasaannya terhadap pekerjaan yang dilakukan. Sedangkan Robbins \& Judge memiliki pendapat bahwa kepuasaan kerja adalah respon individu pada pekerjaannya yang menunjukkan ada ketidaksesuaian antara imbalan yang diterima dengan yang seharusnya diterima (Robbins \& Judge, 2015). Dapat disimpulkan bahwa kepuasaan kerja adalah tingkat kenyamanan seseorang atas peranan dalam pekerjaan. Terdapat dua faktor yang mempengaruhi kepuasan kerja, yaitu faktor yang ada pada diri pegawai dan faktor pekerjaannya (Prabu, 2005). Faktor pertama, diri karyawan, meliputi: kecerdasan khusus, kecerdasan (IQ), umur, jenis kelamin, kondisi fisik, pendidikan, pengalaman kerja, masa kerja, kepribadian, emosi, cara berfikir, persepsi, dan sikap kerja. Faktor kedua yaitu pekerjaannya yang meliputi pangkat atau golongan, jenis pekerjaan, struktur organisasi, kedudukan, mutu pengawasan, jaminan 
finansial, kesempatan promosi jabatan, interaksi sosial, dan hubungan kerja. Apabila karyawan tidak puas dengan pekerjaanya maka ada empat tanggapan yang diberikan yaitu (1) neglect atau sikap acuh tak acuh membiarkan kondisi semakin buruk, (2) voice atau berbicara di mana manajemen organisasi melakukan perbaikan untuk hal yang benar, (3) exit, meninggalkan perusahaan atau organisasi dan yang terakhir adalah (4) loyalty dengan menunjukkan perasaan tidak puas dengan diam, walaupun tetap optimis ada perbaikan keadaan (Robbins \& Judge, 2015).

\section{B. Konflik Peran}

Konflik peran adalah keadaan seseorang yang berhadapan dengan harapan peran yang berbeda (Robbins \& Judge, 2015). Konflik peran adalah kondisi seseorang menjalani pekerjaan yang tidak jelas atau pekerjaan yang saling bertentangan atau diharapkan dapat melakukan pekerjaan lebih dari kemampuan (Handoko, 2008). Konflik peran merupakan kondisi yang menunjukkan ada perbedaan tuntutan pada pegawai karena ada berbagai tindakan yang harus dilakukan yang menyebabkan mereka tertekan secara psikologis (Indrawan, 2009; Tidd \& Friedman, 2002). Konflik peran dapat menghasilkan dampak buruk seperti stres kerja, kepuasan, komitmen, dan turnover karyawan. Konflik peran harus dikelola dengan baik karena jika diabaikan dapat meningkatkan ketidakpastian dan menyebabkan terjadinya stres saat bekerja. Semakin kompleks konflik peran yang terjadi akan semakin meningkatkan stres kerja karyawan yang berarti ada interaksi positif antara konflik peran dan stres kerja (Iqbal, 2013; Yasa, 2017). Selain itu, saat konflik peran naik biasanya kepuasan kerja karyawan cenderung menurun.

Terdapat beberapa faktor yang menyebabkan terjadinya konflik peran yaitu: (a) Masalah komunikasi yang dikarenakan kesalahpahaman yang terjadi terkait kalimat, bahasa, atau informasi yang kurang lengkap serta gaya komunikasi yang tidak konsisten; (b) Masalah struktur organisasi karena adanya pertentangan antar divisi yang memiliki kepentingan atau sistem penilaian yang bertentangan, persaingan memperebutkan sumber daya yang langka atau saling ketergantungan antar tim kegiatan kerja untuk mencapai tujuan; (c) Masalah pribadi karena merasa ada ketidaksesuaian antara tujuan atau nilai sosial individu dengan tingkah laku dan ketidaksamaan persepsi (Siswanto, 2013).

\section{Stres Kerja}

Munculnya stres adalah akibat dari ketidakmampuan dari seorang individu dalam memenuhi harapan dan tuntutan terhadap dirinya (Potale \& Uhing, 2015), sedangkan menurut (Robbins \& Judge, 2015) stres adalah kondisi yang berubah-ubah yang menghadapkan seseorang pada tuntutan, sumber daya, atau suatu peluang yang berkaitan dengan apa yang diinginkan dengan hasilnya yang dirasa penting namun tidak pasti. Dari kedua definisi tersebut, dapat diambil kesimpulan definisi stres kerja adalah suatu tekanan yang dapat menyebabkan keadaan emosi, proses berfikir, dan kondisi dari seorang individu.

Terdapat beberapa penyebab stres diantaranya: (a). Beban kerja yang berlebihan; (b) sikap dan tekanan dari pimpinan yang kurang adil dan wajar; (c) waktu dan peralatan yang mendukung kerja kurang memadai dan waktu yang terbatas; dan (d) konflik antara individu dengan pimpinan atau kelompok kerja. Sedangkan menurut (Robbins \& Judge, 2015) terdapat tiga sumber stres, yaitu: (a) faktor organisasi, meliputi: struktur organisasi, tuntutan tugas, peran, antar individu, kepemimpinan organisasi, dan perluasan organisasi.; (b) faktor individu, meliputi masalah : kepribadian individu, masalah keluarga, atau ekonomi; dan (c) faktor lingkungan, meliputi: ketidakpastian ekonomi, politik, dan teknologi.

\section{Stres Kerja Memediasi Konflik Peran terhadap Kepuasan Kerja}

Merujuk hasil penelitian terdahulu, diperoleh hasil yang menunjukan pengaruh positif yang signifikan antara konflik peran dan stres kerja, konflik peran berkontribusi negatif dengan kepuasan dan stres kerja karyawan, serta stres kerja menjadi mediasi antara konflik peran dan kepuasan kerja (Iqbal, 2013). Namun, penelitian lain menunjukkan hasil yang berbeda, karena konflik peran tidak berpengaruh pada stres kerja (Safaria, bin Othman, \& Wahab, 2011). Penelitian yang dilakukan oleh Yousef pada tahun 2000 mendapatkan hasil bahwa konflik peran tidak memiliki efek interaktif pada kepuasan kerja (Yousef, 2000). Begitu pula penelitian yang dilakukan olehWidyani \& Sugianingrat (2015) yang menemukan bahwa konflik peran tidak berpengaruh terhadap kepuasan kerja (Widyani \& Sugianingrat, 2015). Selain itu, stres kerja tidak mampu memediasi konflik peran terhadap perasaan puas. Berdasarkan beberapa hasil penelitian tersebut menunjukkan hasil yang tidak konsisten. 


\section{MODEL KONSEPTUAL}

Konflik peran yang tinggi akan mengakibatkan munculnya perasaan tegang atau kesulitan menyesuaikan diri dengan pekerjaan sehingga meningkatkan stres pada karyawan. Karyawan yang stres mengakibatkan munculnya ketidaksesuaian antara harapan dan realitas pekerjaan yang dihadapi yang disebut dengan penurunan kepuasan kerja. Berdasarkan uraian tersebut, maka model konseptual dalam penelitian ini ditunjukkan pada gambar 1 .

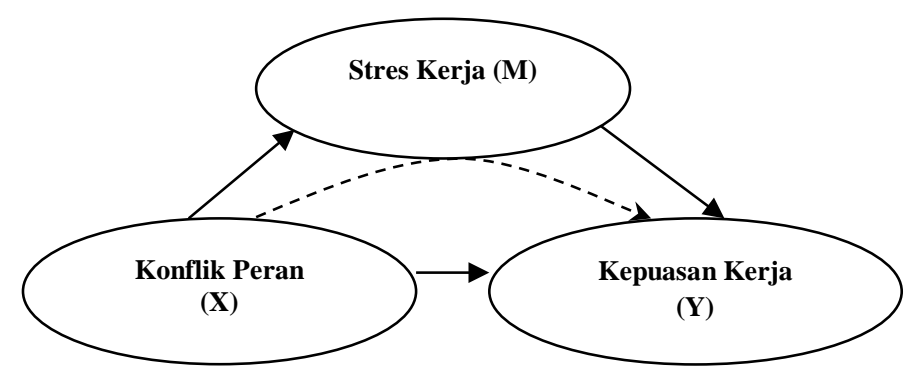

Gambar 1. Model Konseptual (Sumber: Peneliti, 2017)

Adapun pengajuan hipotesis yang yang dibangun dalam penelitian ini adalah:

H1 : Konflik peran berkontribusi positif terhadap stres kerja karyawan

H2 : Konflik peran berkontribusi negatif terhadap kepuasan kerja karyawan

H3 : Stres kerja berkontribusi negatif terhadap kepuasan kerja karyawan

H4 : Stres kerja memediasi konflik peran terhadap kepuasan kerja karyawan

\section{Metode Penelitian}

\section{A. Metode/Rancangan penelitian}

Penelitian ini menggunakan pendekatan kuantitatif dan bersifat sebab akibat (Sugiyono, 2013). Pengukuran penelitian ini menggunakan skala likert yang digunakan untuk menilai respon seseorang atau sekelompok orang tentang fenomena social dengan 5 poin pilihan jawaban mulai sangat tidak setuju sampai sangat setuju. Data penelitian ini meliputi data primer yaitu menggunakan angket pada seluruh karyawan PT. Jombang Intermedia Pers dan melakukan wawancara pada perwakilan manajemen dan karyawan. Sedangkan data sekunder dalam penelitian ini diperoleh dari PT. Jombang Intermedia Pers berupa jumlah karyawan dan urian pekerjaan, artikel jurnal, dan kajian teori yang berhubungan dengan materi kajian. Dalam penelitian ini populasi yang digunakan adalah seluruh karyawan PT. Jombang Intermedia Pers (Jawa Pos Radar Jombang) yang berjumlah 30 orang sehingga teknik penentuan sampelnya disebut sampling jenuh.

\section{B. Identifikasi dan Operasionalisasi Variabel}

Variabel penelitian meliputi : variabel independen (X), variabel dependen (Y), dan variabel mediasi (M).

1. Konflik Peran (X)

Konflik peran adalah respon seseorang yang merasa tidak nyaman dalam bekerja karena sulit menyesuaikan peran yang beragam akibat banyaknya tugas yang harus selesai dalam target waktu yang sama. Konflik peran diukur dengan menggunakan pengukuran yang meliputi : Time based conflict, strain based conflict, dan behaviour based conflict (Rizzo, House, \& Lirtzman, 1970).

2. Stres Kerja (M)

Stres kerja yaitu kondisi seseorang yang tertekan dikarenakan tuntutan pekerjaan yang melebihi kemampuan karyawan. Jenis stres kerja seorang individu yaitu : stres secara fisiologis, psikologis, dan perilaku (Robbins \& Judge, 2015). 


\section{Kepuasan Kerja (Y)}

Kepuasan kerja yaitu tingkat rasa puas individu atas situasi kerja di perusahaan. Pengukuran aspek kepuasan kerja meliputi kepuasan pada pekerjaan individu sendiri, gaji, rekan kerja, atasan, kesempatan promosi, dan lingkungan kerja (Hariandja, 2002).

\section{Teknik Analisis Data}

Data angket online yang sudah masuk selanjutnya dianalisis dengan menggunakan pendekatan deskriptif untuk melihat karakteristik responden dan skor hasil jawaban masing-masing variabel. Selain itu, dilakukan analisis Structural Equation Model (SEM) menggunakan alat bantu Wrap PLS . Structural Equation Model (SEM) merupakan gabungan dari dua metode statistik yang terpisah, yaitu analisis faktor (factor analysis) yang dikembangkan di ilmu psikologi dan psikometri, serta model persamaan simultan (simultaneous equation modelling) yang dikembangkan di ekonometrika (Ghozali \& Latan, 2014).

Dalam uji Wrap PLS di peroleh informasi hasil Inner Model dan Outer Model. Pada analisis Warp PLS, validitas diukur dengan menggunakan dua instrumen, yaitu Convergent Validity dan Discriminant Validity. Begitu juga untuk reliabilitas dengan analisis Warp PLS, reliabilitas diketahui melalui dua instrumen meliputi composite reliability dan alpha cronbach setelah diketahui hasil outer model dan inner model maka dapat digunakan untuk menjawab hipotesis yang dilakukan dengan melihat hasil t-test, jika $p$-value $\leq 0,05$ (Alpha 5\%), maka dapat disimpulkan signifikan, dan begitu pula sebaliknya (Ghozali \& Latan, 2014).

\section{HASil DAN PEMBahasan}

\section{A. Karakteristik Responden}

Hasil penelitian ini mendapatkan informasi tentang karakteristik responden yaitu jenis kelamin dan tingkat pendidikan.

Tabel 1. Jenis Kelamin

\begin{tabular}{ccc}
\hline \multicolumn{3}{c}{ Jenis Kelamin } \\
\hline laki -laki & perempuan & Jumlah \\
24 & 6 & 30 \\
\hline
\end{tabular}

Sumber: data diolah (Spss 15.0)

Dari tabel 1, dapat dijelaskan mayoritas responden adalah laki-laki dikarenakan mayoritas bidang pekerjaan laki-laki berada pada tugas lapangan seperti wartawan dan marketing iklan. Sedangkan perempuan di bidang administrasi.

Tabel 2 merupakan data tingkat pendidikan karyawan di PT. Jombang Intermedia Pers.

Tabel 2.Tingkat Pendidikan

\begin{tabular}{ccc}
\hline No & Tingkat Pendidikan & Jumlah \\
\hline 1 & SMA / SMK sederajat & 5 \\
2 & D3 & 0 \\
3 & S1 & 25 \\
\hline & Total & 30 \\
\hline
\end{tabular}

Sumber: data diolah (Spss 15.0) 
Dari tabel 2, dapat dijelaskan mayoritas pendidikan terakhir responden adalah tingkat S1 dikarenakan tingkat pendidikan S1 merupakan kriteria persyaratan untuk menjadi karyawan Radar Jombang.

\section{B. Hasil Analisis Deskriptif}

Berdasarkan data yang diperoleh dari responden, diperoleh skor jawaban rata-rata variabel yang menggambarkan kondisi konflik peran, stres kerja, dan kepuasan kerja yang dirasakan karyawan. Skor jawaban rata-rata variabel PT. Jombang Intermedia Pers dapat dilihat pada tabel 3.

Tabel 3. Hasil Analisis Deskriptif

\begin{tabular}{lc}
\hline \multicolumn{1}{c}{ Variabel } & Skor rata-rata \\
\hline Konflik Peran (X) & 3,04 \\
Stres Kerja (M) & 2,72 \\
Kepuasan Kerja (Y) & 3,83 \\
\hline
\end{tabular}

Sumber: data diolah (Spss 15.0)

Data pada tabel 3 menunjukkan konflik peran masuk dalam kriteria cukup tinggi yang berarti bahwa mayoritas responden pernah mengalami konflik peran. Selain itu, stres kerja masuk dalam kriteria cukup yang berarti bahwa mayoritas responden sering mengalami stres walaupun tidak terus menerus. Sedangkan kepuasan kerja masuk dalam kriteria tinggi yang berarti mayoritas responden merasa puas akan pekerjaannya.

\section{Hasil Uji Outer Model}

Hasil uji validitas dengan Outer Model dapat dilihat pada tabel 4 berikut.

1. Uji Validitas

Tabel 4. T Square Root Of Ave’s

\begin{tabular}{cccc}
\hline & $\mathrm{X}$ & $\mathrm{M}$ & $\mathrm{Y}$ \\
\hline $\mathrm{X}$ & 0,72 & 0,54 & 0,29 \\
$\mathrm{M}$ & 0,54 & 0,64 & 0,28 \\
$\mathrm{Y}$ & 0,29 & 0,28 & 0,73 \\
\hline
\end{tabular}

Berdasarkan tabel 4, diketahui bahwa nilai root of AVE setiap variabel dari 30 responden lebih besar dari korelasi antar variabel laten pada kolom yang sama. Hal ini menunjukkan bahwa discriminant validity dapat diterima.

\section{Uji Reliabilitas}

Tabel 5. Composite Reliability dan Cronbach’s Alpha Coefficient

\begin{tabular}{ccc}
\hline Variabel & $\begin{array}{c}\text { Composite reliability } \\
\text { coffecient }\end{array}$ & $\begin{array}{c}\text { Cronbach’s alpha } \\
\text { coefficient }\end{array}$ \\
\hline X & 0,86 & 0,80 \\
M & 0,80 & 0,70 \\
Y & 0,93 & 0,91 \\
\hline
\end{tabular}

Sumber: Data diolah (WarpPLS 5.0) 
Dari tabel 5, diperoleh composite reliability setiap variable bernilai di atas 0,7 sehingga dapat diartikan bahwa composite reliability diterima. Untuk cronbach's alpha pada setiap variabel memiliki nilai di atas 0,60 sehingga reliabilitas internal konsistensi diterima.

3. Uji Goodness of Fit (Inner Model)

Kriteria Goodness of Fit Model dapat dilihat pada tabel 6 sebagai berikut:

Tabel 6. Model Fit dan Quality Indiches Warp PLS

\begin{tabular}{|c|c|c|c|c|}
\hline No & $\begin{array}{l}\text { Model Fit and Quality } \\
\text { Indiches }\end{array}$ & Kriteria Fit & Indeks & Kriteria \\
\hline 1 & $\begin{array}{c}\text { Average Path Coefficient } \\
\text { (APC) }\end{array}$ & $\mathrm{p}<0.05$ & 0,438 & Terpenuhi \\
\hline 2 & $\begin{array}{c}\text { Average } R-\text { squared } \\
\text { (ARS) }\end{array}$ & $\mathrm{p}<0.05$ & 0,314 & Terpenuhi \\
\hline 3 & $\begin{array}{l}\text { Average Adjusted } R- \\
\text { squared (AARS) }\end{array}$ & $\mathrm{p}<0.05$ & 0,276 & Terpenuhi \\
\hline 4 & Average block VIF (AVIF) & $\begin{array}{c}\text { Acceptable if }<=5 \text {, } \\
\text { ideally }<=3.3\end{array}$ & 1,012 & Terpenuhi \\
\hline 5 & $\begin{array}{c}\text { Average Full Collinierity } \\
\text { VIF ( AFVIF) }\end{array}$ & $\begin{array}{c}\text { Acceptable if }<=5, \\
\text { ideally }<=3.3\end{array}$ & 1,297 & Terpenuhi \\
\hline 6 & Tanenhaus GoF (GoF) & $\begin{array}{c}\text { Small }>=0.1, \\
\text { Medium }>=0.25, \\
\text { Large }>=0.36\end{array}$ & 0,413 & $\begin{array}{l}\text { Terpenuhi, } \\
\text { kategori large }\end{array}$ \\
\hline 7 & $\begin{array}{c}\text { Sympson's Paradox Radio } \\
\text { (SPR) }\end{array}$ & $\begin{array}{c}\text { Acceptable if } \\
>=0.7, \text { ideally = } 1\end{array}$ & 1,0 & Terpenuhi \\
\hline 8 & $\begin{array}{c}R \text { - squared Contribution } \\
\text { Ratio (RSCR) }\end{array}$ & $\begin{array}{c}\text { Acceptable if } \\
>=0.9 \text {, ideally = } 1\end{array}$ & 1,0 & Terpenuhi \\
\hline 9 & $\begin{array}{c}\text { Statistical Suppression } \\
\text { Ratio (SSR) }\end{array}$ & $\begin{array}{c}\text { Acceptable if }>= \\
0.7\end{array}$ & 1,0 & Terpebuhi \\
\hline 10 & $\begin{array}{c}\text { Nonlinear Bivariate } \\
\text { Causality Direction Ratio } \\
\text { (NLBCDR) }\end{array}$ & $\begin{array}{c}\text { Acceptable if } \\
>=0.7\end{array}$ & 1,0 & Terpenuhi \\
\hline
\end{tabular}

Sumber: Data diolah (WarpPLS 5.0)

Berdasarkan data pada tabel 6, dapat dijelaskan bahwa model sudah fit dengan data sehingga peneliti dapat melanjutkan pengujian berikutnya.

\section{Hasil Uji SEM WrapPLS}

Model dan hasil uji analisis jalur pada penelitian ini ditunjukkan dengan gambar 2 yang memperlihatkan hubungan langsung dan tidak langsung dari variabel yang diteliti. Sedangkan besarnya pengaruh langsung dan tidak langsung ditunjukkan oleh nilai koefisien jalur pada tabel 7. 


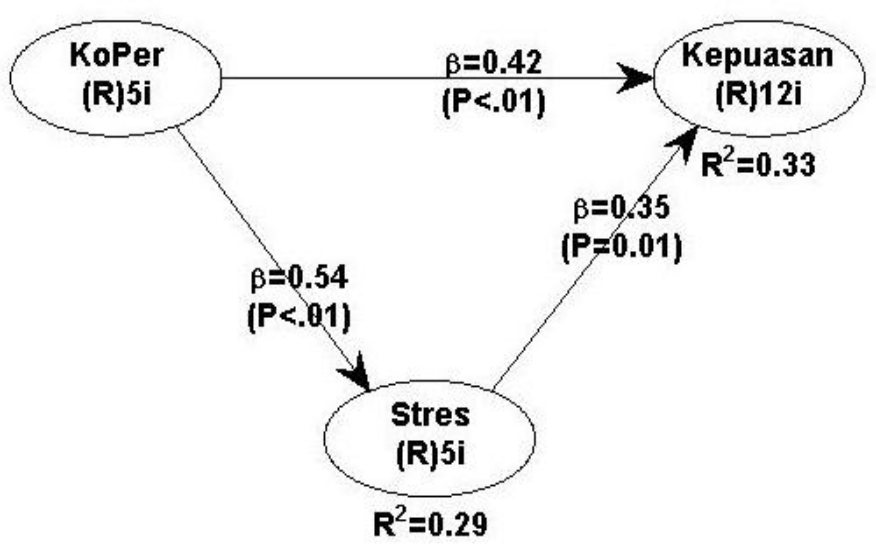

Gambar 2. Direct and indirect effect

Tabel 7. Path Coefficients

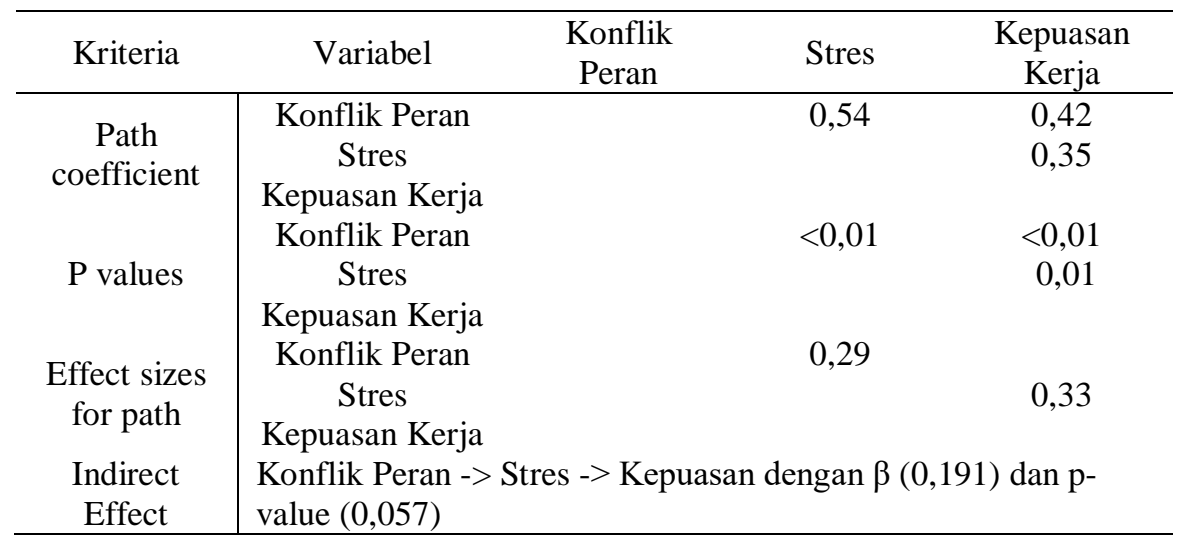

Sumber: data diolah (WarpPLS 5.0)

\section{Pembahasan}

1. Pengaruh konflik peran terhadap stres kerja karyawan

Hasil penelitian yang dilakukan pada karyawan PT. Jombang Intermedia Pers menunjukkan adanya dampak konflik peran pada peningkatan stres kerja karyawan yang berarti apabila semakin sering terjadi konflik peran membuat stres kerja karyawan meningkat. Karyawan Radar Jombang sering mengerjakan beberapa tugas yang harus diselesaikan dalam waktu yang sama sehingga mengalami stres karena dirasa tidak begitu efektif dari sisi waktu dan tenaga. Bentuk stres yang dirasakan yaitu merasa kelelahan, tegang, mudah tersinggung dan bahkan dengan banyaknya pekerjaan yang harus diselesaikan membuat karyawan menyalahkan pekerjaan orang lain. Hasil penelitian ini memperkuat penelitian Iqbal pada tahun 2013 yang memberikan hasil bahwa adanya hubungan positif yang signifikan antara konflik peran dan stres kerja.

2. Pengaruh konflik peran terhadap kepuasan kerja karyawan

Penelitian ini memberikan hasil yang menjelaskan konflik peran berdampak positif pada kepuasan kerja karyawan. Hal ini bertolak belakang pada hipotesis yang diajukan yaitu berpengaruh negatif bukannya positif. Dalam realita, karyawan Radar Jombang masih merasakan terdapatnya kesesuaian antara peran kerja 
dengan harapan mereka. Karyawan menyadari jika pekerjaan mereka memang berat, namun pekerjaan tersebut semestinya dikerjakan. Walaupun karyawan dihadapkan pada berbagai macam pekerjaan yang menyebabkan konflik peran, namun karyawan masih mampu mengontrol diri dari kesadaran terhadap tanggung jawab pekerjaan yang harus diperhatikan sehingga kepuasan kerja karyawan tetap terjaga. Banyaknya pekerjaan tetap membuat karyawan merasa puas terhadap sarana dan prasarana yang mendukung penyelesaian pekerjaan, serta dukungan dari rekan kerja maupun General Manager.

Hasil penelitian menunjukkan bahwa karyawan Radar Jombang memberikan respon yang positif terhadap adanya tuntutan pekerjaan dan tanggung jawab, namun tidak berarti karyawan tidak puas terhadap pekerjaan mereka. Hasil penelitian ini sama dengan penelitian Churiyah pada 2011 yang menyatakan bahwa ada hubungan positif antara konflik peran dan kepuasan kerja. Namun, hasil penelitian ini tidak didukung oleh hasil penelitian Yousef pada tahun 2000 yang menyatakan bahwa individu yang mengalami ambiguitas peran dan konflik peran pada level yang tinggi menyebabkan stres sehingga kurang puas dengan pekerjaannya.

\section{Pengaruh stres kerja terhadap kepuasan kerja karyawan}

Hasil penelitian menunjukkan bahwa stres kerja berdampak positif terhadap kepuasan kerja karyawan. Hal ini berbanding terbalik dengan hipotesis yang diajukan yaitu berpengaruh negatif, bukannya positif. Stres yang dirasakan karyawan Radar Jombang merupakan stres yang positif, dimana seseorang semakin termotivasi untuk mengerahkan segala kemampuan dan sumber daya yang dimilikinya agar dapat memenuhi persyaratan dan kebutuhan kerja. Seorang individu saat menghadapi tekanan kerja yang berat terkadang akan tertantang untuk dapat merampungkannya sehingga akan lebih giat dalam menyelesaikan tugas yang telah dibebankan. Sehingga mereka tidak merasa stres dalam pekerjaannya justru lebih bersemangat untuk bekerja memenuhi ketentuan perusahaan.

Hasil penelitian ini memperkuat penelitian Hanim pada tahun 2016 yang menunjukkan ada hubungan positif yang signifikan antara stres kerja dengan kepuasan kerja. Hasil penelitian yang dilakukan oleh McGee, Goodson, dan Cashman pada 1987 mendapati bahwa beberapa faktor yang menyebabkan pegawai mengalami stres kerja tetapi masih merasa puas terhadap pekerjaannya. Hal ini diantaranya disebabkan oleh tugas yang mereka kerjakan penuh dengan tantangan dan menyenangkan hati mereka. Selain itu terjadi komunikasi yang efektif di antara para anggota dalam organisasi tersebut.

\section{Pengaruh stres kerja dalam memediasi konflik peran terhadap kepuasan kerja karyawan}

Hasil penelitian menunjukkan bahwa stres kerja tidak mampu menjadi mediator konflik peran terhadap kepuasan kerja karyawan. Dalam penelitian ini konflik peran mempunyai hubungan yang positif dan berdampak langsung pada kepuasan kerja karyawan. Dalam kenyataan di lapangan, karyawan Radar Jombang memang merasakan adanya stres kerja namun hanya pada saat-saat tertentu, misalnya pada akhir dan awal bulan ketika deadline semua pekerjaan bersamaan waktu pengerjaan dan pelaporannya.

Hasil penelitian ini tidak mendukung hasil penelitian dari Rohmawati (2016) dan Iqbal (2013) yang menyatakan bahwa stres kerja memediasi pengaruh antara konflik peran terhadap kepuasan kerja. Konflik peran yang dirasakan karyawan Radar Jombang dapat diatasi karena ada dukungan dan kekompakan dari rekan kerja serta atasan dan jalinan komunikasi yang intensif dan efektif. Rekan kerja dan atasan selalu memberikan dukungan dalam beban kerja yang berat sehingga membuat karyawan tetap nyaman bekerja, sehingga kepuasan kerja dengan rekan kerja dan atasan akan meningkat. Kejelasan dan keefektifan komunikasi dalam koordinasi kerja dapat mengurangi potensi konflik peran.

\section{PENUTUP}

Berdasarkan hasil penelitian, di peroleh kesimpulan bahwa konflik peran berperan dalam meningkatkan stres kerja karyawan dan kepuasan kerja karyawan. Selain itu, stres kerja berdampak positif pada kepuasan kerja karyawan yang menunjukkan bahwa jika terjadi peningkatan pada stres kerja, maka kepuasan kerja karyawan meningkat karena diimbangi dengan adanya keterbukaan komunikasi dan kekompakan tim kerja, serta kesadaran karyawan terhadap tanggung jawab. Hasil penelitian juga menunjukan stres kerja tidak mampu menjadi mediasi antara konflik peran pada kepuasan kerja karyawan. 
Berdasarkan hasil penelitian ini, maka dapat diberikan saran kepada perusahaan untuk melakukan evaluasi proses kerja sehingga mengurangi terjadinya konflik peran bagi karyawan. Hal ini dapat di atasi dengan mengurangi beban kerja yang melebihi kemampuan yang dimiliki karyawan. Selain itu, karyawan Radar Jombang perlu meningkatkan kesadaran diri dan memahami bahwa pekerjaan tersebut memang sudah menjadi tanggung jawabnya. Untuk penelitian selanjutnya, diharapkan untuk mengungkap hasil penelitian sejenis yang menjadi research gap bagi stressor yang berdampak pada kepuasan kerja karyawan, karena hasil penelitian ini menunjukkan konflik peran menjelaskan kepuasan kerja rendah dan stres kerja tidak mampu menjadi mediasi antara konflik peran dan kepuasan kerja karyawan.

\section{DAFTAR PUSTAKA}

Akwan, N. M., Suprapti, N. W. S., \& Sintaasih, D. K. (2016). Peran Kepuasan Kerja Dalam Memediasi Pengaruh Konflik Peran Dan Stres Kerja Terhadap Intensi Keluar (Studi Pada Anantara Seminyak Resort \& Spa, Bali). Jurnal Relasi Stie Mandala Jember, 12(1).

Alfian, F., Adam, M., \& Ibrahim, M. (2018). Pengaruh Keterlibatan Kerja, Beban Kerja Dan Konflik Peran Terhadap Kepuasan Kerja Serta Dampaknya Pada Kinerja Pegawai Pada Dinas Pendidikan Aceh. Jurnal Manajemen Dan Inovasi, 8(2).

Churiyah, M. (2011). Pengaruh konflik peran, kelelahan emosional terhadap kepuasan kerja dan komitmen organisasi. Jurnal Ekonomi Bisnis, 16(2), 145-154.

Ghozali, I., \& Latan, H. (2014). Partial Least Squares Konsep, Metode dan Aplikasi Menggunakan Program WarpPLS 4.0. Semarang: Badan Penerbit Universitas Diponegoro.

Gu, Z., \& Chi Sen Siu, R. (2009). Drivers Of Job Satisfaction As Related To Work Performance In Macao Casino Hotels: An Investigation Based On Employee Survey. International journal of contemporary hospitality management, 21(5), 561-578.

Handoko, T. H. (2008). Manajemen Personalia dan Manahjemen Sumber Daya Manusia, edisi kedua, cetakan keenambelas, penerbit: BPFE: Yogyakarta.

Hanif, R. A. (2013). Pengaruh Struktur Audit, Konflik Peran, dan Ketidakjelasan Peran Terhadap Kinerja Auditor. Jurnal Ekonomi, 21(03).

HANIM, M. L. (2016). Pengaruh Stres Kerja Terhadap Kepuasan Kerja Serta Dampaknya Pada Kinerja Karyawan Hull Construction Di Pt. Dok Dan Perkapalan Surabaya. Jurnal Ilmu Manajemen (JIM), 4(3).

Hariandja, M. T. E. (2002). Manajemen sumber daya manusia: Grasindo.

Indrawan, R. (2009). Pengaruh Konflik Peran Terhadap Stres Kerja Dengan Ketidakpastian Dan Kepuasan Kerja Sebagai Variabel Mediasi (Studi Pada PT. Air Mancur Karanganyar). Universitas Sebelas Maret.

Iqbal, N. (2013). Impact of Role Conflict on Job Satisfaction, Mediating Role of Job Stress in Private Banking Sector. Interdisciplinary Journal of Contemporary Research In Business, 14, 711-722.

Jung, H. S., \& Yoon, H. H. (2015). The Impact Of Employees' Positive Psychological Capital On Job Satisfaction And Organizational Citizenship Behaviors In The Hotel. International journal of contemporary hospitality management, 27(6), 1135-1156.

Kong, H., Jiang, X., Chan, W., \& Zhou, x. (2018). Job Satisfaction Research In The Field Of Hospitality And Tourism. International journal of contemporary hospitality management(just-accepted), 00-00.

McGee, G. W., Goodson, J. R., \& Cashman, J. F. (1987). Job Stress And Job Dissatisfaction: Influence Of Contextual Factors. Psychological Reports, 61(2), 367-375.

Naibaho, Y. F. K. N. K., \& Sawitri, D. R. (2018). Hubungan Antara Regulasi Diri Dengan Konflik Peran Pada Mahasiswa Organisatoris di FKM dan Fisip Universitas Diponegoro. Empati, 6(3), 204-2011.

Nur, I. R., Hidayati, T., \& Maria, S. (2017). Pengaruh Konflik Peran, Ambiguitas Peran Dan Stres Kerja Terhadap Kinerja Karyawan. Jurnal Manajemen, 8(1), 1-18.

Potale, R., \& Uhing, Y. (2015). Pengaruh Kompensasi dan Stres Kerja Terhadap Kepuasan Kerja Karyawan Pada PT. Bank Sulut Cabang Utama Manado. Jurnal EMBA: Jurnal Riset Ekonomi, Manajemen, Bisnis dan Akuntansi, 3(1).

Prabu, M. A. (2005). Manajemen Sumber Daya Manusia Perusahaan. Bandung: PT. Remaja Rosdakarya.

Prajuna, A., Febriani, F., \& Hasan, L. (2018). Dampak Pengelolaan Kecerdasan Emosional dan Stres Kerja terhadap Kinerja Karyawan pada PT MNC Sky Vision KPP Padang. Manajemen dan Kewirausahaan, $8(2), 15-26$.

Rizzo, J. R., House, R. J., \& Lirtzman, S. I. (1970). Role Conflict And Ambiguity In Complex Organizations. Administrative science quarterly, 150-163. 
Robbins, S. P., \& Judge, T. A. (2015). Perilaku Organisasi (Organizational Behavior)(Edisi 16). Jakarta: Salemba Empat.

Rohmawati, I. S. N. (2016). Pengaruh Ambiguitas Peran Terhadap Kepuasan Kerja Karyawan Dengan Stres Kerja Sebagai Variabel Mediasi Pada PT Waskita Beton Precast Plant Sidoarjo.

Safaria, T., bin Othman, A., \& Wahab, M. N. A. (2011). The Role of Leadership Practices on Job Stress among Malay Academic Staff: A Structural Equation Modeling Analysis. International Education Studies, 4(1), 90-100.

Siswanto, S. (2013). Manajemen Sumber Daya Manusia Reformasi Birokrasi dan Manajemen Pegawai Negri Sipil: Bandung: PT. Refika Aditama.

Sugiyono, P. (2013). Metode Penelitian Manajemen. Bandung: Alfabeta, CV.

Tidd, S. T., \& Friedman, R. A. (2002). Conflict Style And Coping With Role Conflict: An Extension Of The Uncertainty Model Of Work Stress. International Journal of Conflict Management, 13(3), 236-257.

Widyani, A., \& Sugianingrat, I. (2015). Effect Of Multiple Role Conflict On Job Satisfaction With The Mediation Role Of Stress. International Journal of Economics, Commerce and Management, 3(5), 868870.

Yasa, I. W. M. (2017). Pengaruh Konflik Peran dan Ambiguitas Peran Terhadap Kinerja Pegawai Melalui Mediasi Stres Kerja Pada Dinas Kesehatan Kota Bali. Jurnal Ekonomi \& Bisnis, 4(1), 38-57.

Yousef, D. A. (2000). Organizational Commitment: A Mediator Of The Relationships Of Leadership Behavior With Job Satisfaction And Performance In A Non-Western Country. Journal of Managerial Psychology, 15(1), 6-24. 